received from the Director of the Victoria and Albert Museum, with the generous consent of the Board of Education, a tall silk hat and a soft straw hat which were Darwin's : as a matter of history, the size is $7 \frac{1}{4}$, possibly smaller than might have been supposed. Both the letter and the hats are now on exhibition at Down House.

\section{Commemoration of Robert Hooke at Oxford}

A Representative Oxford gathering met in the Divinity School on November 20 to do honour to the memory of Robert Hooke of Christ Church, who was born three hundred years ago. Dr. R. T. Gunther, reader in the history of science, presided. The Warden of Now College gave an address on the earliest 'Oxford Movement', that resulted in the formation of the Royal Society and, in particular, on the manifold activities in science and art of Hooke and Christopher Wren in London during the reign of Charles II. He pointed out why it was that the former, despite his many qualities, missed supreme greatness. Dr. Gunther spoke of Hooke's discoveries in mechanics, optics, biology and astronomy, and of his great inventive genius generally. Dr. Russell said what could be said of the work done in relating combustion and respiration to the gas afterwards named oxygen. Accounts were read of Hooke's activities in geology and other subjects. The Dean of Christ Church recalled in a witty speech some of the admirable qualities which Hooke showed as a man. He afterwards opened an exhibition devoted to Hooke's work, arranged by Dr. Gunther in one of the rooms of the Old Ashmolean Building. This contained early editions of the "Micrographia" including the beautiful original plates, books owned and annotated by Hooke, modern books about him, models of his microscope, of his mechanical inventions and of the apparatus he used in demonstrations. Particularly interesting was a photograph of the first foraminifer figured and described by Hooke in 1661. There was a nice collection of drawings and photographs of the buildings that Hooke had designed. Prof. F. Soddy had had prepared many models to illustrate different modern applications of Hooke's joint. He demonstrated their working to the visitors, and spoke of the applications of the joint made more than sixty years ago by Franz Reuleaux.

\section{T. H. Huxley as Anthropologist}

Sir Grafton ElLtot-Smith made an especially happy choice of subject for his Huxley Memorial Lecture to the Royal Anthropological Institute on November 26, when he spoke on "The Place of Thomas Henry Huxley in Anthropology"-a topic which, as he pointed out, has been neglected, curiously enough, in the many lectures delivered previousty in memory of Huxley. Yet Huxley was not only mainly responsible for the amalgamation of the two rival societies concerned with anthropological studies, which led to the foundation of the Anthropological Institute in 1871, but he was also the real founder of the scientific study of man in Great Britain. By his insistence on the biological point of view in the study of man, he effectually disposed of the loose and facile argument on so-called evolutionary lines, which paraded in the 'sixties of the last century as scientific theory. In emphasising man's place in Nature, he provided the science of human biology with its chief instrument, the means of interpreting and applying to mankind the knowledge acquired by the investigation of man's nearest kindred and merging it in biology as a whole. In recalling the controversy, now almost forgotten, over the 'Hippocampus', in which Sir Richard Owen figured, Sir Grafton rightly stressed the importance of Huxley's identification and pioneer work on the calcarine region which made possible the definition of the characters that conferred its unique qualities on the human brain. Incidentally, he revealed that Huxley's work on this subject was the starting point of his own investigations of the brain and the comparative study of the development of its functions, especially in connexion with the acquisition of stereoscopic vision and its consequences for human evolution.

\section{New Foreign Members and Correspondents of the Geological Society of London}

AT the meeting of the Geological Society of London on November 20, Prof. C. P. Berkey and Prof. P. D. Quensel were elected foreign members, and Prof. F. Broili and Dr. E. P. de Oliveira foreign correspondents, of the Society. Prof. Charles P. Berkey, of Columbia University, is well known to geologists in Great Britain as the secretary of the Geological Society of America, a position he has held since 1922. His publications cover a wide field, but in recent years have been principally devoted to the geology of Mongolia, and have appeared as the reports of the Central Asiatic Expeditions of the American Museum of Natural History. Prof. Percy Quensel, of the University of Stockholm, has on several occasions lectured in Great Britain. His researches have been devoted principally to the elucidation of the problems of the petrology and structural features of the older rocks of Sweden; but he has also published papers on the geology and petrology of Patagonia. Prof. Ferdinand Broili, of the University of Munich, is noted for his studies on the fossil reptiles and Stegocephalians, and has also published papers on the Permian brachiopods and the Devonian trilobites. Dr. Euzebio Paulo de Oliveira is the director of the Serviço Geologico e Mineralogico do Brasil. His published works have been principally descriptive of the mineral resources of Brazil.

\section{Air Transport Exhibition at the Science Museum}

AN exhibition portraying the organisation and operation of the air services over Empire air-routes will be opened at the Science Museum, South Kensington, by the Secretary of State for Air on December 5, and will be on view to the public from December 6 until January 31. The exhibition, which is being organised and staged by Imperial Airways Ltd., is popular in character, both in scope and treatment, and will illustrate the development of air communications within the Empire by means of 